\title{
Viver com HIV/Aids em contextos descentrados: articulações e modos de pensar (em torno de) subjetividades políticas*
}

\author{
Thiago de Lima Oliveira** \\ Éverson de Brito Damasceno*** \\ Lucas Pereira de Melo****
}

\begin{abstract}
Resumo
Este artigo aborda o modo como categorias de diferenciação como sexualidade, geração, classe social e lugar são corporificados em trajetórias de vida de pessoas vivendo com HIV/aids em cidades interioranas do Nordeste brasileiro. Nesse sentido, buscamos explorar a articulação entre noções de pessoa, práticas de cuidado e de conhecimento à luz da constituição de subjetividades políticas. A proposta é ampliar o olhar sobre processos de sofrimento social, sexualidade e saúde e suas complexas relações que conferem sentido e lugar ao vírus, ao cuidado, ao adoecer e suas economias de conhecimento.
\end{abstract}

Palauras-chave: HIV/Aids, Experiência Com a Enfermidade, Sexualidade, Geração, Lugar.

\footnotetext{
* Recebido em 23 de outubro de 2018, aceito em 15 de março de 2021.

** Doutorando em Antropologia Social (USP); pesquisador vinculado ao Laboratório de Antropologia Urbana (LabNAU/USP), São Paulo, SP, Brasil. thi_oliveira@usp.br / http://orcid.org/0000-0002-1175-013

*** Médico residente em Psiquiatria no Hospital Universitário Lauro Wanderley da Universidade Federal da Paraíba, João Pessoa, Paraíba, Brasil. Pesquisador vinculado ao Laboratório de Pesquisas Sociais em Saúde e Enfermagem (LASSEN/USP). everson.damasceno@outlook.com / http://orcid.org/0000-0001-5882-019X

**** Professor Doutor do Departamento de Enfermagem Psiquiátrica e Ciências Humanas da Escola de Enfermagem de Ribeirão Preto - Universidade de São Paulo. Pesquisador vinculado ao Laboratório de Pesquisas Sociais em Saúde e Enfermagem (LASSEN/USP). Ribeirão Preto, SP, Brasil. lpmelo@usp.br / http://orcid.org/0000-0001-8392-1398
} 
Living with HIV/AIDS in Peripheral Contexts: Articulations and Modes of Thinking about Political Subjectivities

\begin{abstract}
This article investigates how categories of differentiation such as sexuality, generation, social class, and place are embodied in life trajectories of people living with HIV/aids in cities in the interior of Brazil's Northeast. We explore the articulation between notions of personhood and practices of care and knowledge considering the constitution of political subjectivities. The objective is to broaden the view on processes of social suffering, sexuality, and health and their complex relationships that confer meaning and place to HIV, care, illness and their economies of knowledge.
\end{abstract}

Keywords: HIV/AIDS, Experience with illness, Sexuality, Generation, Place. 


\section{Introdução}

Juarez ${ }^{1}$ caminhava com um passo reto através do corredor longínquo do hospital onde foi marcado nosso primeiro encontro. O olhar atento reunia sinais de reconhecimento do cenário ali instaurado e de seus personagens, mas também algum desconforto pelo vai $e$ vem das pessoas. Tal movimento se fazia por meio de olhares que mapeavam quem entrava em cada sala e estabelecia cálculos sobre eventos, sortes, acontecimentos. Seria ele também implicado nessa economia do rumor e dos vestígios na qual saber onde ele entraria e a suposição dos fins desencadearia comentários, fofocas e informações sobre seu cotidiano no cenário afetivo de Jardim de Piranhas ${ }^{2}$, a cidade na qual nascera e para onde havia voltado há alguns anos.

O caminhar reto de Juarez contrastava com o acelerado das vozes, sua e de outras pessoas, com as quais interagia no trajeto, com o constante enfiar de mãos na pequena bolsa a tiracolo, com a vida dos enfermos que passavam uma parte de seus dias nos leitos, consultórios e salas de espera. Nosso olhar se dirigia a ele com alguma sensação de familiaridade, ainda que não o tivéssemos conhecido ${ }^{3}$. O primeiro contato com Juarez se deu no hospital de Jardim de Piranhas, porque era o dia em que a médica infectologista que mediou nosso encontro estava de plantão. Eles se conheciam desde que Juarez voltou de seus trânsitos pelo Sudeste. Foi a médica quem telefonou para ele e o convidou a comparecer ao hospital naquele domingo, pois uns rapazes da

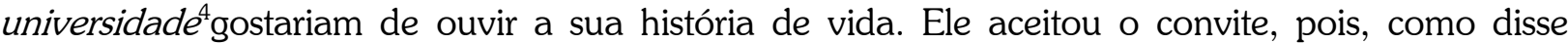
repetidas vezes, achava importante contar a sua história de vida e como era ser gay ali em Jardim de Piranhas.

Na compreensão de Juarez, contar sua história era, também, uma maneira de colocar esse passado em perspectiva e colaborar com os gays novinhos. A atmosfera ambígua, de suspeição e reconhecimento, de Juarez não era muito diferente da nossa. Buscávamos potenciais colaboradores para execução de uma pesquisa sobre as experiências de viver com o vírus da imunodeficiência humana/síndrome da imunodeficiência adquirida (HIV/aids) em contextos que usualmente passam despercebidos, por estarem infiltrados em recônditos pouco notados pela produção acadêmica, política e histórica sobre a epidemia, pelos processos de resposta e enfrentamento, fosse a partir do Estado; fosse a partir de pessoas e coletividades autogeridas.

Foi no corredor que encontramos Juarez pela primeira vez, ali, sentado entre cadeiras que pareciam desconfortáveis. Nosso encontro era marcado por assimetrias. Suspeitávamos, olhando as pessoas no corredor e em toda a unidade de saúde, que nosso possível colaborador poderia ser aquela pessoa do olhar apressado e atento, pele branca e já marcada pelos seus sessenta e poucos anos de idade, vestindo um short jeans e uma camiseta de cor alaranjada em tonalidades combinando. Juarez, contudo, talvez não suspeitasse que seríamos nós os tais rapazes da universidade que queriam lhe conhecer.

O tema da conversa era caracterizado por uma divergência implícita em cada um dos sujeitos do encontro. Para a equipe do hospital, tratava-se de uma conversa sobre o acesso ao serviço de saúde e ao tratamento. Juarez, por sua vez, parecia acreditar na nossa conversa como uma entrevista sobre a experiência de descobrir-se vivendo com HIV. Já nós, pretendíamos tão somente conhecer um pouco sobre sua vida, e, também, como lidava com o serviço de saúde e a experiência de adoecimento. De todo modo, o lugar que o vírus HIV ocupava em cada uma dessas possibilidades de descrição do nosso encontro sinalizava algumas das preocupações que orientaram

\footnotetext{
1 Todos os nomes de pessoas citados no artigo são fictícios. O projeto foi aprovado pelo Comitê de Ética em Pesquisa da instituição nos termos da Resolução nº 510/2016 (Parecer n ${ }^{\circ}$ 1.947.922/2017).

2 Jardim de Piranhas é um município do sertão potiguar, região do Seridó do estado do Rio Grande do Norte a 299Km da capital, Natal. Segundo estimativas do Instituto Brasileiro de Geografia e Estatística (IBGE) possuía 14.858 habitantes em 2017.

${ }^{3}$ Escrevemos na primeira pessoa do plural, pois a pesquisa envolveu três pesquisadores (um estudante de graduação, um doutorando em Antropologia e um professor que coordenava a pesquisa). Nossas presenças nos encontros com Juarez variaram, de maneira que só um de nós manteve uma relação mais próxima e regular com ele.

4 Ao longo do texto convencionamos a utilização de aspas duplas para indicar fragmentos de falas do interlocutor. Termos e expressões recorrentes empregados por ele e que são importantes para a organização das ideias apresentadas também foram incorporados à redação deste artigo e estão sinalizados para leitoras e leitores por meio do itálico.
} 
a elaboração deste trabalho. O conhecimento partilhado sobre sua sorologia parecia desobrigar um momento de relação, constituindo assim um dado do nosso encontro e a partir do qual ele se desenrolaria. Contudo mesmo ocupando um a priori, um elemento dado da construção do vínculo entre pesquisadores e pessoas com as quais pesquisávamos, no contexto de comprometimento moral configurado por cenários como os aqui descritos, falar sobre o HIV/aids com a guarda baixa, como dizia Juarez, narrar suas experiências com um mínimo conforto oferecido pela ausência de uma sala de consultório, de microfones ou de uma plateia parecia criar um espaço de reflexão e de constituição de intimidades que posicionava de outro modo os efeitos do estigma, da sujeição e da fala pública.

O presente artigo é um exercício de pensar noções de pessoa e sofrimento social a partir de um contexto de cruzamentos. Trata-se de um cruzamento à medida que nos interessa analisar trajetórias de vida de pessoas vivendo com HIV/aids em contextos descentrados, marcados por formas de identificação, reconhecimento e constituição de si que usualmente escapam às reflexões sistemáticas no campo da antropologia ou sociologia do corpo e da saúde em busca da compreensão sobre as configurações de subjetividades infletidas pela experiência de viver com o HIV/aids. O espaço de reflexão aqui produzido é o das cidades interioranas do nordeste brasileiro tendo em vista a rentabilidade de uma reflexão que considere a constituição imbricada de pessoa e lugar para descrever processos de saúde-doença e dos modos de conceituação de si. Pensar o contexto de produção dessas experiências e trajetórias de vida é também um exercício de articulação de práticas de conhecimento organizadoras de sentidos para as pessoas, seus corpos $e$ afetos e para os loci nos quais coreograficamente esses sentidos são colocados em jogo.

Ao começarmos a análise do material coletado ao longo das diversas entrevistas que realizamos em campo, no curso de quase dois anos de investigação, não era interesse ou pretensão construir um universo de narrativas biográficas individuais. Em alguma medida, não era também nosso interesse construir um processo de experimentação etnográfica sobre noções de pessoa, lugar, adoecimento, saúde e sofrimento a partir de uma única pessoa, como o apresentado aqui. Contudo, no curso da investigação e da análise do material, a trajetória de Juarez parecia sinalizar importantes questões que diziam respeito a pontos nodais e recorrentes na análise de outras experiências inseridas nos espaços geográficos e temporais sobre os quais nos debruçávamos. Essas questões implicavam não só nossos temas no início da pesquisa, mas também discussões sobre movimentos de partida e retorno, laços familiares, moralidades e modos não institucionais de se relacionar com a política como ética do cuidado e da vida.

O material aqui apresentado foi reunido em diversas ocasiões nas quais realizamos entrevistas formais com utilização de gravadores, ou nas quais pudemos conversar; faz parte dele também, em dimensões não tão explícitas, a participação e acompanhamento de eventos realizados em Caicó e na vizinhança das pequenas cidades que compõem a região que tem 25 municípios, sendo Currais Novos e Caicó seus principais núcleos urbanos. Essas cidades atuavam como polos magnéticos na gestão da economia, dos postos de trabalho e acesso a níveis mais elevados de escolarização, lazer e serviços. Nas relações cotidianas, elas também se colocavam como pontos de referência a partir dos quais se estabeleciam escalas entre capital e interior, cidade polo e cidades secundárias, de maneira que nas relações entre Caicó e Jardim de Piranhas, por exemplo, a primeira se colocava como um centro; embora ambas, quando em relação com a capital do estado, fossem consideradas interior ou sertão.

Nosso interesse principal aqui é apresentar algumas possibilidades interpretativas para a compreensão disso que entendemos como subjetividades políticas. Acompanhando Rahimi Sadeq (2015), é possível pensar em subjetividade política a partir de dois eixos. Um primeiro que considera como a interação constitui a cultura, e um segundo que tem em conta o papel constitutivo das relações na produção da subjetividade. A partir desses eixos é possível pensar a presença do conceito em outras tradições filosóficas e antropológicas, a exemplo da noção de inconsciente político em Fredric Jameson (1992). Seja partindo da análise da relação entre esquizofrenia e história, como no caso de Sadeq, ou entre opressão e literatura, como no caso de Jameson, ambos os autores oferecem elementos para pensar os mecanismos sutis que aproximam o sujeito aos eventos que constituem o contexto em que vivem, considerando-os de modo articulado. 
A aposta parte dessa compreensão conjunta para pensar as instâncias discretas do político, ou seja, as relações, as táticas e as interações que constituem burocracias, moralidades e negociações do cotidiano e que compõem a política como um modo de organização da vida não apenas em seu nível institucional ou macro. Afastando-nos de Sadeq (2015) e Jameson (1992), nosso interesse diz respeito menos às disputas que constituem a subjetividade no embate entre sistemas de significado, pois buscamos pensar as práticas, os movimentos $e$ as trajetórias que estabelecem negociações entre significados locais e globais no contexto de experiências vividas e narradas. Tal perspectiva diz respeito aos processos de infiltração, coprodução e mutualidade que constituem o universo de relações e sentidos que conferem valor e lugar a como sujeitos pensam a si mesmos.

Ao pensarmos em torno de subjetividades políticas nosso propósito é esmiuçar os contornos morais, históricos, políticos, sociais e culturais inscritos na sociogênese de experiências do sofrimento social (Kleinman; Das; Lock, 1997), como as narradas por Juarez. Isso porque nossa hipótese é que a política, como modo de relação com a vida e com as coletividades que a constituem, refere-se à gestão das formas de significação que dizem respeito à vida social, sendo assim também parte dos movimentos de organização social nos quais estão empenhados os grupos humanos em suas relações com outros modos de existência (humanos e não humanos).

Pensada nesses termos, as questões aqui esboçadas se aproximam das reflexões de Biehl (2007) sobre os processos de medicalização e subjetividade, de Paul Rabinow (1997) sobre biosocialidade e de Paul Rabinow e Nikolas Rose (2006) sobre as reconfigurações contemporâneas da noção foucaultiana de biopoder. Ainda que coloquem sob escrutínio experiências localizadas em escalas distintas àquelas com as quais trabalhamos aqui, esses autores oferecem elementos para pensar práticas e moralidades que repercutem nos modos como sujeitos sociais interpretam a experiência do adoecimento, sofrimento e estigma, conectando contextos e escalas de práticas $e$ significados. Ao partirmos desta compreensão, chamamos a atenção aos fluxos e às relações que constituem os territórios interioranos e sertanejos e nos afastamos das imagens estereotipadas dessas localidades. Nosso intento é reaproximar esse debate das questões específicas da experiência de viver com HIV/aids a partir de eixos de politização da vida e reflexão político-epistemológica particulares, tendo em vista o modo como a presença do vírus e seus âmbitos de interpelação instauram sentidos e reposicionam narrativas sobre moralidades, religiosidades, conhecimento, economia, corpo e pessoa em um movimento interpretativo quase dramático.

\section{Drama, gatilho e aventura}

As narrativas de Juarez tinham como gatilho um drama familiar que implicou na sua expulsão da casa dos pais, na década de 1970, quando ainda tinha 17 anos de idade. A despeito das situações de abandono e preterimento protagonizadas por ele e por seu pai desde a infância, Juarez cresceu sendo distinguido nas relações familiares e naquelas que se davam em outros espaços da cidade (notadamente nas escolas onde estudou) como um "menino diferente dos demais, afeminado, delicado demais". Essa diferença que, como problematiza Brah (2006), o diferenciava dos outros meninos hierarquicamente e não lateralmente, ganhava relevo em várias situações narradas por Juarez. Contudo, uma delas se configurou como um drama na medida em que resultava de uma contínua tensão entre conflito e harmonia, e, no caso em tela, circunscrevia-se mais às relações familiares e afetivo-sexuais de Juarez. Em suas palavras:

Pedro estudava comigo no Diocesano [tradicional escola católica do Seridó potiguar, localizada em Caicó, onde costumavam estudar as classes médias e altas da região. Juarez estudou nessa escola como bolsista] e o irmão dele que era mais baixinho e feinho. Pedro se interessava de ficar comigo, mas eu queria era o irmão dele, Júnior. Mas eu nunca tive coragem de chegar para ele e admitir que gostava dele. Se ele percebeu, porque de toda forma a gente demonstra o que sente, ele ficou na dele. E Pedro dizia assim: "Como são as coisas: eu quero ficar com você, mas você corre atrás do meu irmão que nem te percebe direito". Júnior ia muito para o hotel [onde Juarez trabalhava à época] fazer companhia e ficar sentado comigo. De noite eu esperava o ônibus que vinha de Natal para Juazeiro, o Corujão. Era meia-noite. Ele só ia embora quando eu fechava o hotel. Mas nunca passou disso pra nada. Foi nessa época que descobri que meu pai estava tendo um relacionamento com uma mulher que ficava lá no hotel. Eu fui dizer a ela 
que iria contar para a minha mãe. Eu achava que era certo falar com ela, sabe, porque na minha cabeça ela tinha que deixar meu pai. Foi quando essa mulher chegou para o meu pai $e$ disse que eu era viado, que eu vivia ficando com esse menino [Júnior], que dormia comigo, que a rua todinha sabia... Então, quando eu cheguei em casa, ele estava em pé na porta. Eu achei estranho, eu senti uma coisa que não sei explicar, como um aviso, aquela pressão sobre o meu peito... Quando eu fui chegando ele já disse: "você saia daqui, se retire! Pegue o que é seu e vá embora, porque você não é mais meu filho. Você é um viado e eu não quero um viado dentro da minha casa". Nessa hora minha mãe se atravessou no meio e disse que se eu fosse, iria comigo. Ele disse: "você vá e não volte". Ela respondeu: "num volto, num preciso voltar, mas você pode ter certeza que eu venho buscar os outros [filhos]". E ela vinha mesmo. Mas daí foi que entrou meus tios para tentar acalmar, e os vizinhos... Porque todo mundo gostava dela $e$ viram todo o problema que estava acontecendo na calçada (Juarez, entrevista, janeiro de 2018).

Interessante notar a relação entre os espaços que se cruzavam nesse drama: a escola, o hotel $e$ a rua, como arenas públicas; a casa e a calçada, como arenas privadas. Além de trazer à calçada da casa os conflitos existentes na família (conjugais, relação pai e filho, homossexualidade), esse drama resultou na expulsão de Juarez de sua casa pelo pai. Em pequenas cidades do interior do Nordeste, como Jardim de Piranhas, a palavra rua não significa só um logradouro público utilizado para assinalar endereços, localizações. No sentido empregado por Juarez, a rua envolve, principalmente, o centro da cidade, um espaço de relações mediadas pela noção de público, como veremos adiante. Ir à rua é mais que sair da interioridade da casa, uma vez que, notadamente em bairros de periferia, a rua onde se mora tende a ser, em alguma medida, também casa. Por isso, o drama narrado por Juarez tem início na calçada, na soleira da casa e, depois, adentra seu átrio. A calçada é, portanto, um espaço ambíguo na medida em que coloca em relação as noções de público e privado. Talvez por isso, nesses lugares, é comum observar que as calçadas das casas são personalizadas ao gosto dos moradores (coloca-se azulejos, cerâmicas, pinturas, plantas, bancos), além de ser cenário de relações e conversações entre vizinhos, amigos e familiares.

Argumentamos aqui que a rua e cidade são um par análogo no contexto etnográfico. Se como argumenta DaMatta (1997a), a rua é o equivalente simbólico e material oposto ao da casa, ainda que não sejam fechados em si, é a despeito dessa possibilidade de abertura que certas práticas, como a fofoca e o rumor, produzem embaralhamentos. Sendo assim, gostaríamos de pensar rua e cidade não apenas como cenário, mas, acompanhando Marques (2015:113), como um "dado relacional da equação" aqui traduzida no exercício de articular espaço, diferença $e$ moralidades.

No mesmo dia do drama familiar que levou à exposição da sua homossexualidade e à infidelidade conjugal paterna, Juarez foi colocado pelo seu tio dentro de um ônibus que saiu de Caicó, de madrugada, com destino ao Rio de Janeiro ${ }^{5}$. Nos anos seguintes, as relações foram se diluindo $e$ tornando indiretas. Eram mediadas por parentes que transmitiam notícias e, posteriormente, por remessas de dinheiro. A adolescência de Juarez em Jardim de Piranhas, sua partida para o Rio de Janeiro e o retorno à cidade natal, quase 25 anos depois, nos permitiram explorar algumas camadas do cotidiano em sua trajetória de vida que constituíam a série de eventos, movimentos e sujeitos. Esses elementos fazem parte do modo como Juarez interpreta sua relação com a cidade e constrói uma perspectiva para descrever as relações e trânsitos entre política, segredos, lugares e cuidados.

Para Juarez, ser expulso de casa pelo pai e a consequente ida para o Rio de Janeiro, em 1976, significou, num primeiro momento, uma aventura, dado seu caráter inusitado expresso no fato de só ter "onze cruzeiros e uma bolsinha pequena, mas sem roupa nem nada". Nesse sentido,

\footnotetext{
${ }^{5}$ As relações entre mobilidades e vivências da sexualidade têm um longo histórico nas ciências sociais brasileiras. Ilustrativo disso são os trabalhos de Carmen Dora Guimarães (2004 [1977]) e parte da discussão posta por Richard Parker (2002 [1999]). Esse debate tem sido particularmente intenso no contexto de experiências de mulheres trans e travestis, considerando as negociações com trabalho, violência e produção corporal (cf. Vale, 2005; Patrício, 2008). No contexto desta pesquisa, contudo, nos interessa a mobilidade mais em termos de retorno do que de partida. Ou seja, nos interessa pensar os efeitos e negociações implicados no processo de Juarez retornando à Jardim de Piranhas. Para uma discussão mais profunda sobre gênero, sexualidade e retorno, ver Verônica Guerra (2019).
} 
o estar lá fora ${ }^{6}$ ganhou relevos distintos. Se, por um lado, as circunstâncias da viagem foram dolorosas, por outro, ir ao Rio dava contornos e materialidade a um conjunto de oportunidades: ser aceito como homossexual, superar as dificuldades próprias das famílias de classe popular, trabalhar, ganhar dinheiro e ser feliz. Juarez sempre ouvia falar sobre lá fora nas conversas informais e escondidas com os hóspedes do hotel de sua tia em Jardim de Piranhas. Ele mantinha algumas relações com esses homens, "mas eram mais trocas de abraços, de beijos. Não tinha sexo, penetração. Uns queriam amizade e não passava mais do que isso. Já outros, vendo a oportunidade de ter algo mais, mesmo sendo casados, avançavam" ${ }^{7}$. Nessas conversas, o lá fora era descrito como um lugar de aceitação da homossexualidade e das formas de relação entre pessoas semelhantes em termos de sexo e/ou gênero, da desvinculação dos dispositivos de localização usuais em sua cidade (onde ele não seria o filho de Seu Sicrano e Dona Beltrana ${ }^{8}$ ), de pessoas educadas, esclarecidas. Ele sempre quis "saber qual era a diferença" que existia entre Jardim de Piranhas e lá fora. Em seus encontros com os hóspedes, os quais costumavam estimulálo a "sair da cidade, procurar morar em lugares mais adiantados", o que, em alguma medida, se coadunava à perspectiva de que nesses contextos interioranos se dispunha de um "equipamento cultural precário", como colocado por Eunice Durham (1984) em sua etnografia sobre migração de trabalhadores rurais para São Paulo, que ata e tensiona seus habitantes, sendo a emigração uma solução possível. Dessa forma, o Rio se tornou parte de um imaginário social sobre a cidade grande, porém inscrito nas particularidades da vida de um jovem que se viu obrigado a fazer de um drama familiar, uma aventura.

Segundo nos relatou, ele "saiu triste, mas feliz". Nessa ambiguidade, tristeza (por sair de casa e deixar a família, principalmente a mãe e os irmãos) e alegria (pela oportunidade de conhecer lá fora) se complementavam. Chegando ao Rio, foi acolhido por uma prima que ele chamava de enfermeira9. Essa prima dividia apartamento com outras cinco mulheres da mesma profissão. Ao mesmo tempo em que a prima era um apoio, representava a moralidade interiorana de Jardim de Piranhas. Já as amigas que moravam com ela o orientavam a elaborar um projeto de vida mais condizente com valores de uma modernidade materializada nas representações da cidade grande (autonomia, anonimato, racionalidade, impessoalidade, independência etc.) que, em muito, se contrapunha às tradições e aos laços de parentesco e vicinais que Juarez trazia de Jardim. Segundo narrava, elas diziam que "eu tinha que ter minha vida, que eu não tinha que ter preconceito, que eu não voltasse mais para Jardim, porque se não iria passar tudo de novo...". Em outros momentos, ele se deparava com formas de preconceito, mais veladas, diferente daquelas com que estava acostumado. Tanto que, para ele, soava como brincadeiras das enfermeiras. "Juarez, seis moças solteiras aqui e você um rapaz novo e bonito. A gente querendo que você nos esquente, mas a gente sabe que o seu negócio é outro!"

\section{"Eu resolvi dar meu grito": geração, sexualidade e lugar na trajetória de vida de Juarez}

Com cuidado e querendo "ganhar a vida", Juarez fez cursos profissionalizantes na Cruz Vermelha e no Serviço Nacional de Aprendizagem Comercial (SENAC) - o primeiro, por indicação da prima; o segundo, por sugestão de um vizinho. O curso de barman no SENAC fez mais sentido para ele, pois "gostava de trabalhar atendendo pessoas, lembrava do hotel em Jardim". Logo ele estava trabalhando em um hotel e a partir daí novas relações foram sendo construídas.

\footnotetext{
6 Segundo Juarez, "lá fora" abrangia os estados do Rio de Janeiro, São Paulo e Minas Gerais. Por vezes, podia incluir a Bahia

7 Em geral, esses hóspedes ficavam no hotel não mais que três dias e foram descritos por Juarez como sendo "pessoas educadas, esclarecidas, que me tratavam bem".

8 Essas referências eram sempre acionadas, sobretudo em momentos de "denúncias". Juarez nos contou das fofocas que faziam para sua mãe quando, na juventude, ia brincar com os amigos no rio da cidade: "Olhe, seu filho está ali dentro do rio! Está com fulano! Estão fazendo sexo! Coisa feia, são dois homens!"

9 Interessante notar a prática comum de se denominar "enfermeira" todas as profissionais da área de enfermagem, sem distinguir, portanto, as categorias de auxiliar de enfermagem, de técnico de enfermagem e de enfermeira. Na narrativa de Juarez essa especificidade não ficou esclarecida.
} 
No Rio de Janeiro, Juarez iniciou suas incursões no mundo social gay mediadas por três amigos: Souza, Júlio e Neves. O último era o mais velho do grupo, o Grandão. Ele sempre orientava Juarez nos cuidados que precisava ter na relação com outros homens e, quando necessário, também o defendia fisicamente. Esses novos amigos foram responsáveis por apresentar o mundo das saunas, dos "bares GLS" (gays, lésbicas e simpatizantes) ${ }^{10}$ e das boates a Juarez:

\begin{abstract}
Eu morava com minha prima, mas andava com eles. Eles procuravam a independência deles e me chamaram. Foi muito bom, porque eu era muito ingênuo e eles foram me mostrando as coisas, cuidavam de mim, me protegiam e prestavam atenção quando eu estava lá pela boate. Quando tinha um cara que queria se aproveitar, eles chegavam junto e impediam. Começaram a me levar nas saunas gays, e eles pagavam tudo, já que eu não tinha condições. Eles compravam roupas para mim, me levaram para conhecer seus familiares. Então eu fui vendo que era uma amizade sincera, que eram pessoas direitas e que queriam me ajudar. Alguns não tinham juízo! Eram pá-virada, como diziam [risadas]. Neves era o mais velho, o grandão, $e$ as pessoas tinham até medo dele. Então ele dizia para eu sempre ficar por perto e não ir na onda dos outros. Porque eles eram experientes e eu não tinha experiência ainda (Juarez, entrevista, janeiro de 2018).
\end{abstract}

Nessas relações, Juarez foi experimentando ser uma pessoa, antes de ser viado - como era visto e tratado em Jardim de Piranhas - um atributo depreciável que afetava sua identidade e a deteriorava, como explicou Goffman (2008). Ou seja, se em Jardim de Piranhas o estigma lhe parecia como uma marca fixa, as novas amizades e as experiências em outros mundos sociais, nomeadamente o gay, deixaram em evidência o estigma como uma "linguagem de relações" (Goffman, 2008:13), de maneira que pode ou não se dá a estigmatização. Um desses indicativos era ser levado "para conhecer seus familiares", já que o espaço da casa e suas relações não se dão entre estranhos, entre indivíduos, mas entre pessoas cujas existências se legitimam pelos elos relacionais que mantêm umas com as outras (DaMatta, 1997a). Nesse sentido, tais experiências de diferenciação, classificação e hierarquização de diferenças sociais precisam, como nos alerta Brah (2006), ser pensadas de maneira relacional e contextual.

Juarez foi tecendo relações mediadas pela ideia de amor, de cuidado, de carinho e de "calor humano", quiçá essa tenha sido uma das diferenças percebidas por ele entre a vida em Jardim de Piranhas e a vida lá fora. Paralelamente, as saídas nas sextas-feiras à noite, após o trabalho, iam se tornando, cada vez mais, momentos de felicidade, alegria, sorrisos fáceis, amizades, liberdade, experimentações corporais (dança, beijo, relaxamento) e de satisfação da curiosidade sobre "o que ocorria entre dois homens". Com o tempo, os sentimentos de arrependimento, culpa e frustração após essas saídas que, na sua visão, tinham a ver com sua criação, com seus princípios, foram se tornando pontuais e esparsos.

Aos poucos, o rapaz de 17 anos foi conhecendo pessoas e com elas passou a aprender, a esclarecer, a descobrir o mundo gay e, com isso, desconstruiu o que se falava a respeito de viados, especialmente, mas também de outras identidades sexuais tidas como dissidentes. Entre o trabalho no hotel, a moradia com as enfermeiras e as noites badaladas com os amigos, Juarez foi sendo iniciado numa gramática de desejos por meio da qual, paulatinamente, ressignificava a identificação estigmatizada de viado e construía uma outra: a de homossexual. Essas experimentações se deram no contexto social e político do fim dos anos 1970 quando, a despeito da ditadura militar em curso, despontava um conjunto de práticas de socialidade nos espaços urbanos de algumas cidades brasileiras (notadamente Rio de Janeiro e São Paulo) caracterizado pelo aumento de bares, discotecas/boates e saunas voltadas ao público homossexual masculino de classe média (Green, 2000) - talvez por isso, os amigos de Juarez necessitassem "pagar tudo" para ele. De acordo com Trevisan (2000), esse período também ficou conhecido como o "desbunde guei", dada a maior visibilidade dos homossexuais na cena cultural e política brasileira, o que significava "mandar às favas" o sistema político e reivindicar uma liberalização individual e sexual.

\footnotetext{
${ }^{10}$ Sobre o processo de institucionalização dos movimentos sociais em questões de sexualidade no Brasil e os sentidos das siglas para representá-los, ver Facchini (2005).
} 
Em sua narrativa, ele destacou, em vários momentos, o rito de iniciação ao mundo gay do Rio de Janeiro - uma iniciação que implicava em revisar e ressignificar diversos aspectos de sua história de vida e de eixos de produção e visibilização da diferença: lugar de origem, orientação sexual, classe social, escolaridade, geração, religiosidade. Nesse cenário, Juarez aprofundava suas experiências afetivo-sexuais para além das "trocas de abraços e beijos" que mantinha, às escondidas, com os hóspedes do hotel em Jardim de Piranhas. Nas saunas, bares e boates gays cariocas, ele conheceu "homens casados, bissexuais, ativos, passivos, viados". Só aí ele manteve sua primeira relação sexual com penetração e, dessa vez, sem "medo de levar a culpa, sem ter feito nada".

A distância da família, nomeadamente do pai, representava uma possibilidade de engajamentos afetivo-sexuais antes evitados. Ao mesmo tempo novas amizades se formavam $e$ Juarez foi conhecendo outros homens que mantinham relações com mulheres (casamentos, namoros e noivados), em geral identificados como bissexuais. Esses relacionamentos lhe permitiram, cada um à sua maneira, aprender novas emoções: amor, desejo, tesão, companheirismo, saudade. Se num primeiro momento, Juarez relatou que viajou para o Rio num ônibus que saiu na madrugada de Caicó com uma "bolsinha pequena" sem nada em seu interior, aos poucos ele deixou escapar os projetos e desejos que a preenchia (ou que talvez foram lhe preenchendo ao longo do caminho): "eu queria ter uma oportunidade na vida para voltar [para Jardim de Piranhas] e mostrar que eu tinha superado tudo!". Certamente, as experimentações dessa gramática de desejos lhe oportunizaram voltar "por cima da carne seca"!

No fim dos anos 1990, antes de retornar para Jardim de Piranhas em 2000 e "mostrar que tinha superado tudo", Juarez mudou de cidade novamente, dessa vez para Uberlândia, Minas Gerais, onde foi diagnosticado como pessoa vivendo com HIV. O vírus já era um conhecido, visto que ele viu sua emergência nos anos 1980. Desde então, o HIV rondava suas relações, pois alguns de seus amigos, inclusive um ex-namorado, morreram de aids. Tratava-se, portanto, de um fantasma que percorria "os leitos, as paqueras, os flertes" (Perlongher, 1987:7), um terror que produzia o rompimento e o esfacelamento dos vínculos sociais, dificultando ou impedindo as trocas simbólicas (Pereira, 2004).

Essa "experiência compartilhada de sofrimento" foi descrita por Zamboni (2015:77) como uma ruptura brutal, uma vez que "articula a dor vivida no corpo doente, a infiltração da dor sentida por corpos próximos e um sofrimento associado às perdas (que é uma das dimensões do luto)". Em sua narrativa, Juarez destacou que o vírus era seu conhecido não só pela convivência com amigos soropositivos, mas também pelas materialidades dos discursos midiáticos e o pânico moral em torno da epidemia de HIV/aids que não só enquadrou corpos específicos por meio de estratégias de governamentalidade, como também fez incidir sobre eles as medidas mais austeras da biopolítica (Sanches e Barbosa, 2015). O vírus como um "conhecido" aponta para duas instâncias que merecem atenção. A primeira, é do encontro entre diferentes práticas de conhecimento e escalas que tornam alguns debates próximos a certos grupos sociais, ainda que distantes geograficamente. A segunda, é a função restauradora da ordem social instituída pela aids como um dispositivo e o pânico moral.

Na primeira, trata-se de pensar a aids e seu potencial de gerar significados. Uma epidemia de significação (Treichler, 1987), construída nos interstícios entre o global e o local; e de disputas entre narrativas biomédicas, midiáticas, religiosas, dentre outras. Jonathan Mann apontou, em 1987, a existência de três fases da epidemia, ou três epidemias: a primeira caracterizada pela infecção pelo HIV; a segunda, anos depois, marcada pela doença em si; e a terceira, decorrente dos momentos anteriores, é a emergência da aids e suas significações (Mann, WHO Special Programme on AIDS, 1987). Em suas análises do caso brasileiro, Daniel e Parker (1991), afirmaram que a terceira epidemia chegou ao país antes mesmo da primeira, tornando, de fato, o HIV num conhecido de pessoas como Juarez, pois seus efeitos se fizeram sentir em corpos, sexualidades, espaços e desejos dissidentes. Assim, a aids foi construída como uma doença contagiosa, sexualmente transmissível (mas não em todas as práticas sexuais), incurável e com desfecho inevitavelmente fatal, o que permitiu não só a produção de um novo elenco de personagens, já vinculados à marginalidade 
social e moral (homossexuais, trabalhadoras sexuais, usuários de drogas injetáveis e outros), mas a sua associação a noções de contaminação, contágio e perigo (Daniel e Parker, 1991).

A segunda instância, tributária que é da primeira, retirou a aids do rol das "doenças comuns", como sugeriu Daniel (1991), e a alçou ao lugar de uma metáfora (Sontag, 1989), condição sinequa non para sua introdução numa teia de moralizações que, segundo Perlongher (1987), lhe permitiu funcionar como um dispositivo, no sentido foucaultiano. Dispositivo, porque pôs em operação uma rede de poder-saber na qual se inscreveram "discursos, instituições, organizações arquitetônicas, decisões regulamentares, leis, medidas administrativas, enunciados científicos, proposições filosóficas, morais, filantrópicos" (Foucault, 2010:244). A aids como um dispositivo foi significada como uma "doença homossexual" e passou a ser conhecida dado ao "poderoso mecanismo de moralização e controle, derivado das ondas de pânico" (Perlongher, 1987:9). Logo, o pânico moral em torno da aids era, também, um refluxo do desbunde dos anos 1970, algo vivenciado por Juarez em suas incursões no mundo gay carioca e, como discutido anteriormente, fundamental na sua construção como homem homossexual. Esses mecanismos de moralização e controle permitiram localizar a aids, discursiva e materialmente, a meio do caminho entre a "tragédia pessoal" e a "calamidade coletiva", como ensaiado por Rubin (2017:112) em sua análise sobre a aids no contexto das guerras sexuais estadunidenses. O conhecido, aqui o vírus, aproxima assim diferentes níveis de estranhamento: de lugar, de relação e de prática de conhecimento.

Entre Uberlândia e o retorno à Jardim de Piranhas, Juarez já tinha se transformado num homem feito, trabalhador, independente financeiramente e que sempre ajudou a família com o envio de dinheiro, além de ter construído uma ampla rede de apoio social. Nas duas décadas em que esteve afastado de Jardim de Piranhas, as relações com a família, ainda que instáveis pela figura do pai, foram cultivadas e mediadas por remessas em dinheiro, notícias e conversas esporádicas por telefone. No Rio e em Uberlândia, as possibilidades de encontro e descoberta de si $e$ da sexualidade conjugavam-se às memórias da infância e juventude, bem como à saudade de amigos e parentes deixados.

A procura por atendimento médico em Uberlândia foi motivada por um câncer de pele. Como medida terapêutica, a quimioterapia era uma certeza no seu tratamento. Todavia, os resultados do exame de sangue "mostraram" que suas plaquetas estavam extremamente abaixo do valor preconizado pela biomedicina. Sem uma causa aparente que justificasse esse sangue ralo, o médico solicitou mais exames laboratoriais na tentativa de elucidar o diagnóstico, incluindo, claro, a sorologia para o HIV. A palavra "claro" aqui faz alusão à tendência de redução da condição de saúde de pessoas com orientações sexuais e/ou identidades de gênero não heterossexuais $e$ cisgêneras nos protocolos médicos às infecções sexualmente transmissíveis. Nessa perspectiva, a abordagem integral costuma dar lugar à outra, genitalizadora, que reduz a pessoa às suas práticas sexuais e seu corpo aos órgãos que utiliza para dar e receber prazer sexual, geralmente sem função reprodutiva.

Para Juarez a confirmação da sorologia positiva foi um "baque muito grande" e embora tenha convivido e presenciado o processo de adoecimento de seu parceiro em 1985, nunca havia parado para imaginar que o mesmo aconteceria consigo. Ele afirmou que, na época (fins dos anos 1970 e início dos 1980), pouco se discutia ou se preocupava com o uso de preservativos nas relações sexuais. Nunca se fazia questão de usar e ninguém ficava pensando que podia "dar doenças pelo sexo". Naquele contexto, a ideia de "dar doença", atualizada pela epidemia de HIV/aids, se contrapunha à imagem das ciências da vida, notadamente da medicina, como invencíveis no combate às doenças transmissíveis, dado o estágio de desenvolvimento tecnológico do pós-guerra (Czeresnia, 1995). Por outro lado, a produção discursiva institucional-estatal do sexo desprotegido (leia-se, sem uso de preservativo masculino) disparou um processo de acusações e de gestão de algumas vidas produzindo assim uma "remedicalização da sexualidade e a recolonização dos corpos que estavam parcialmente livres do império médico" (Patton, 1990:54). No contexto das tecnologias de gestão do prazer e do risco, o uso de preservativos nas relações sexuais foi (e continua sendo), certamente, uma das estratégias que "abriram" as portas desses corpos que se tornaram a aids. 
Na ciência médica da Aids, o corpo se torna uma tela ou uma placa de Petri [agarplate] no qual a doença se desenvolve/age. (...) Os diagnósticos médicos abstraem os sintomas do corpo para produzir uma explicação totalizante com uma causa única ou primária, uma patologia. Já que o sistema imunológico, metaforicamente, transcende o espaço do corpo, a abstração "AIDS" volta-se exatamente para o espaço do corpo. O vírus está perdido e, metaforicamente falando, o corpo do homossexual, da prostituta, do africano, do usuário de drogas injetáveis e do hemofílico torna-se AIDS. O homem gay é a representação/embodiment paradigmática do "vírus da AIDS" (Patton, 1990:55, grifos da autora, tradução nossa ${ }^{11}$ ).

Nesse sentido, o diagnóstico foi um momento de forte intensidade, de múltiplas faces, de múltiplas dores, visto que atualizou ou trouxe para perto esse sofrimento que é de todos e de cada um, como evidenciado por Zamboni (2015) e Saggese (2015) em suas etnografias com homossexuais paulistanos que vivenciaram a eclosão da epidemia em suas juventudes. Na experiência de Juarez, o viver com HIV/aids dividia a cena, também, com a luta contra um câncer agressivo. Apesar de nos anos 2000 a resposta brasileira à epidemia estar num momento de ascensão, sobretudo devido à distribuição universal dos antirretrovirais (ARV) ${ }^{12}$, e já se falar da cronificação da infecção pelo HIV, o peso do diagnóstico foi maior que o do câncer. Ele narrou esse peso como caracterizado por sentimento de tristeza, de angústia, de desespero e até mesmo vontade de desistir de tudo dada a morte anunciada. Além disso, essa condição lhe trouxe o medo das reações familiares e do preconceito dos outros - algo que atualizava experiências vividas na adolescência.

No período que se seguiu, Juarez teve à sua disposição a solidariedade de pessoas amigas $e$ conhecidas: o patrão, colegas de trabalho, amigos do Rio, vizinhos. Além disso, a espiritualidade teve papel central. Em sua narrativa, a religiosidade aparece como uma das principais fontes de apoio e de chave de compreensão da sua vida e da nova condição. O espiritismo, a umbanda e o catolicismo permitiram a Juarez produzir chaves analíticas que lhe ajudaram a interpretar sua trajetória de vida: a relação conflituosa com o pai, a ligação com a mãe, a saída forçada de Jardim de Piranhas, as dificuldades enfrentadas, as pessoas que apareceram em sua vida e o ajudaram ("não tinha estudo, mas sempre aparecia alguém para orientar, aconselhar, ajudar") e a ressignificação da condição de viver com o HIV/aids como um "resgate de outras vidas". Foi assim que Juarez voltou para o sertão nordestino motivado, nomeadamente, pela necessidade de cuidar dos seus pais idosos e adoecidos.

O retorno para a casa da família não foi fácil, pois o pai, mesmo doente, dizia: "você é um viado! Eu não quero que você cuide de mim!" A relação com a mãe se aprofundou ainda mais, a ponto de ele precisar viajar para que ela pudesse desencarnar: "quando ela desencarnou, eu não estava aqui. Fui para Natal, porque ela não conseguia desencarnar com minha presença. Eu estava prendendo o espírito dela aqui". Por outro lado, as pessoas da cidade continuavam como antes, pelo menos em termos de fofoca: "lá fora não tem isso [fofoca]. Eu vivi em uma cidade pequena de Minas Gerais e nunca vi isso por lá: olhe, fulano é viado!" Mas aquele adolescente que não tinha "coragem de expressar o que sente, de dizer que está gostando [de um rapaz], sem tomar iniciativa" voltou para dar uma virada: "eu resolvi dar meu grito". Em sua casa ${ }^{13}$, o espaço dedicado à sua espiritualidade é motivo de orgulho (Figuras 1). Durante nossa última entrevista, já em sua casa, ele apresentou e explicou cada uma das imagens de santos católicos e de entidades da umbanda, além de alguns elementos espíritas.

\footnotetext{
${ }^{11}$ No texto de partida: "In AIDS medical science, the body becomes a screen or agar plate on which disease is in play. (...) Diagnostic medicine abstracts the symptoms from the body to produce a totalizing explanation with a single or primary cause, a pathology. Because the immune system, understood metaphorically, transcends the place of the body, the abstraction "AIDS" folds back to correspond exactly to the space of the body. The virus is lost and, metaphorically speaking, the homossexual/prostitute/African/injecting-drug-user/hemophiliac body becomes AIDS. The paradigmatic representation/embodiment of the "AIDS virus" is the gay man".

${ }^{12}$ Garantida pela Lei Federal $n^{\circ}$ 9.313, de 13 de novembro de 1996 que dispõe sobre a distribuição gratuita de medicamentos aos portadores do HIV e doentes de AIDS.

${ }^{13}$ Após a morte dos pais, Juarez ficou morando na casa da família sozinho e mantém um espaço (um quarto) onde realiza seus cultos "espíritas", segundo ele. Há ali um sincretismo entre espiritismo kardecista, umbanda e catolicismo.
} 
Figura 1 - Vista parcial do quarto de orações e preces

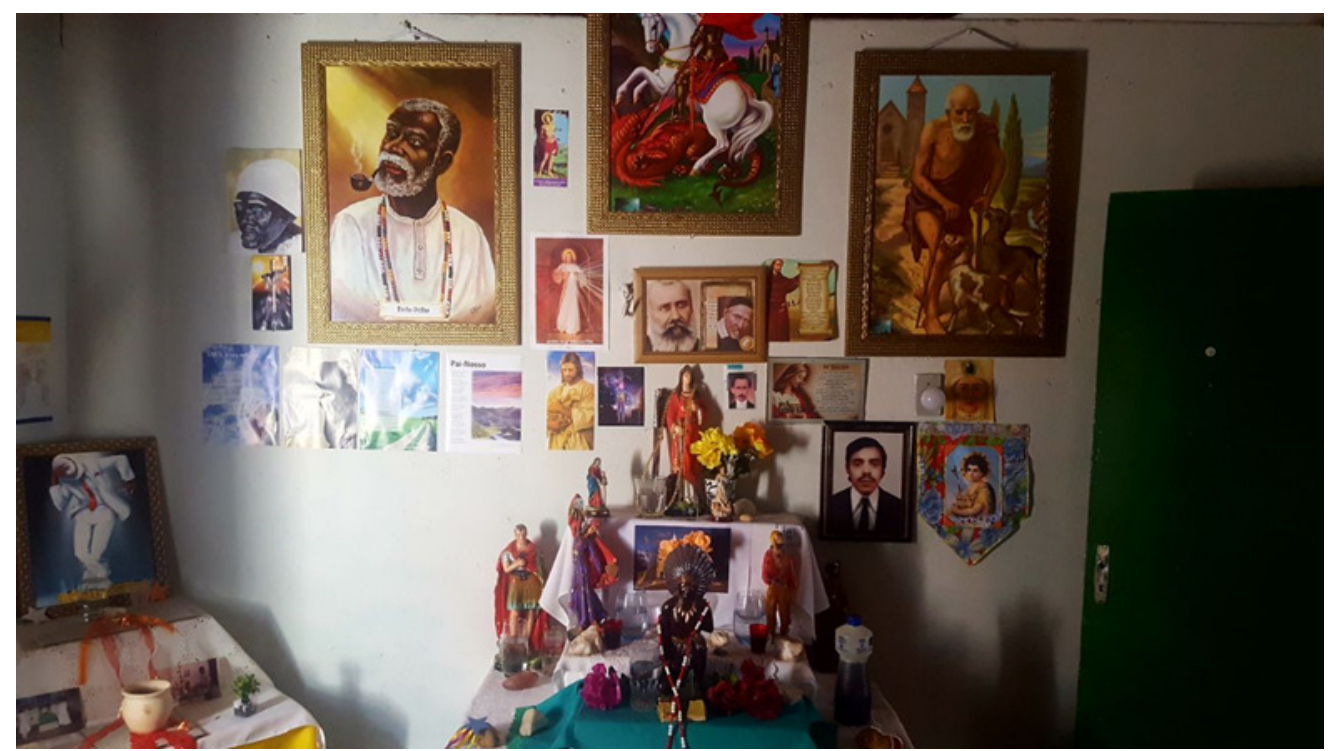

Fonte: acervo dos autores.

Nos momentos em que estivemos juntos, Juarez demonstrava uma necessidade de "dar seu grito" como uma forma de tensionar a intolerância das pessoas da cidade para com os diferentes. Fazia isso, inclusive, pensando nas novas gerações, pois "os novinhos sofrem uma pressão muito grande da cidade". Ao mesmo tempo em que buscava resistir contra a "memória dos pais": "porque, mesmo após a morte dos meus pais, as pessoas ainda dizem assim: olhe, não leve ninguém para sua casa [para transar], porque é a memória dos seus pais. Nem os amigos você deve levar lá. (...) Depois que passei a rebater, eles me deixaram em paz". Nesse aspecto, a religiosidade cumpria um papel importante, pois cada uma das entidades, orixás e santos católicos (Iansã, São Lázaro, Oxóssi, Iemanjá, Oxum, Ondinas, São Jerônimo, Pretos Velhos, Pretas Velhas, Zé Pilintra, Exus e Pomba Gira) presentes em sua casa tinham um papel fundamental nessas políticas de diferenciações, enunciações, resistências e desejos.

Fiz que nem a Pomba Gira disse: "Cadê sua força? Bata seu pé e diga quem você é para as pessoas te respeitarem". Eu era muito assim: cabeça baixa, chorava e só ouvia o que as pessoas falavam. Hoje em dia eu resolvi dar meu grito. E esse ano [2018] o que eu mais quero é sair de quenga no bloco do carnaval! (...) Não é que seja a voz da verdade, mas eu queria dar um grito que pudesse dizer chega a isso tudo. Porque alguém tem que começar. É tudo muito quieto... O pessoal da saúde põe uma camiseta sobre HIV, um laço vermelho e pronto! Você acha que isso resolve? Tem rádio, hospital, vários postos de saúde, médicos bons... Só falta combater isso! Por mim não tem problema. Eu já estou no fim da vida, com 66 anos. Nada me atinge, pois, eu já passei por tudo. Mas, e os que estão começando? Eu tenho amigos que estão em casa, frustrados, querendo colocar a corda no pescoço ${ }^{14}$, porque a sociedade não aceita sua sexualidade. E não tem ninguém que faça nada! Não é só aqui. Existe em todo canto (Juarez, entrevista, janeiro de 2018).

Essa fruição de resistências ganhava ainda mais sentido naquele momento de sua vida, quando tentava manter uma relação de amizade com um rapaz mais jovem da cidade, mas precisava enfrentar os preconceitos ligados à homossexualidade e, sobretudo, ao viver com HIV/aids entre seus próprios amigos. Para ele, essas atitudes remontavam a um passado que julgou ter sido superado: "eu achei que tinha mudado pela televisão, pela informação... Mas hoje eu percebo que não mudou nada. O outro já olha para você com aquele mesmo julgamento de viado!". No trecho acima, Juarez vislumbrava em sua vida interseções entre gênero, sexualidade,

\footnotetext{
${ }^{14}$ Ele se refere às mortes por suicídio. Na região do Seridó potiguar há uma taxa de mortalidade significativa por suicídio, principalmente entre adultos e idosos. Para uma análise epidemiológica desse fenômeno na região, ver Santos e Barbosa (2017).
} 
HIV/aids e lugar, embora também percebesse que essas questões estavam presentes em todos os lugares, mesmo lá fora, ainda que se conformassem de maneiras diversas em cada contexto.

Nesse sentido, a crítica à maneira de fazer a política de saúde no município e a suposta negação dessas circunstâncias e configurações socioculturais das problemáticas em tela, fez Juarez escolher o bloco de carnaval As Quengas ${ }^{15}$ como um espaço de trânsitos e encontros para dar seu grito:

O que isso significa para mim? Significa dar um grito de liberdade! Mostrar que sou capaz, que sou homossexual, que tenho HIV, mas que não preciso me esconder atrás das pessoas. Significa que eu sou feliz do meu jeito. Porque tem muitos comentários por aí e os novinhos sofrem uma pressão muito grande da cidade. Vão [pessoas que praticam atos de homofobia] para lá [bloco das quengas] criticar, jogar pedra, chamar de viado. E eu quero mostrar que não é assim. Eu quero ir ao bloco com um cartaz bem grande atrás de mim, escrito: "Não ao preconceito!" Eles vão saber que sou eu (Juarez, entrevista, janeiro de 2018).

Sendo assim, vestir-se de "quenga" no carnaval poderia significar também radicalizar com a ampliação da questão, na medida em que, além da orientação sexual já publicamente conhecida, brincar com a identidade de gênero tencionaria ainda mais essas políticas de atribuição de identidade.

Em muitos aspectos, as condições de possibilidade que tornavam e conferiam contorno à condição pública da sorologia de Juarez estavam assentadas na posição que todos assumiam nos debates locais e nas suas experiências com outras formas de fazer política através dos ativismos e da militância. No caso de Juarez, ele participou de atividades vinculadas à igreja e, mais recentemente, às iniciativas de caridade no centro espírita ao qual estava vinculado. A partir de redes específicas, ele produzia sentidos para suas experiências com o HIV/aids, seus interesses na pauta e colocava no debate público particularidades, desafios e estigmas que perpassavam sua vida e a potencialidade da construção de redes de apoio, cuidado e sensibilização.

Cruzamentos, articulações e modos de pensar (em torno de) subjetividades políticas em contextos descentrados

As trajetórias, experimentações e vivências narradas por Juarez nos falam sobre certas condições públicas do viver com o HIV/aids, sobretudo, em lugares distantes dos grandes centros metropolitanos. Essa condição pública é marcada por uma série de componentes que devem ser qualificados para entender os sentidos e valores que a ideia de "público" possa vir a ter. A condição pública é importante por permitir o cruzamento de dois eixos. Por um lado, o público é aquilo com o qual se tem que negociar as moralidades que conformam noções de segredo e confiança na experiência de viver com HIV. Por outro lado, também é o espaço material e simbólico da política, contrastando com o domínio doméstico/privado. As formas condensadas de fofoca e rumor embaralham essas posições, como se viu no gatilho que levou à saída de Juarez da cidade. A política é aqui entendida como um modo de organização da vida, e, como argumenta Besnier (2009), fofocas e rumores têm uma posição de destaque por permitir seu trânsito entre doméstico/privado e público/coletivo. Essas possibilidades de negociar limites são descritas aqui em termos de uma microeconomia do conhecimento, em profundo diálogo com a formação da subjetividade política.

No contexto de uma microeconomia do conhecimento da qual participam pequenas cidades como Jardim de Piranhas, "público" pode não ser sinônimo de uma informação acessível a qualquer um. Antes, é uma modalidade de relação articuladora de perspectivas sobre intimidade, lugar, segredo e seus efeitos. Subjetividade política, moralidade e economias do conhecimento

\footnotetext{
${ }^{15}$ Esses blocos carnavalescos são bastante comuns nas festividades de rua de várias cidades brasileiras. No Nordeste, especificamente, esses blocos são presenças quase obrigatórias nas programações das capitais (como "As Virgens do Bairro Novo", em Olinda-PE; "As Virgens de Tambaú", em João Pessoa-PB) e das pequenas cidades do interior (como "As Catraias", em Carpina-PE; "As Quengas do Magão", em Caicó-RN). Para uma discussão sobre o protagonismo travesti em blocos dessa natureza em Fortaleza-CE, ver Veras (2017). Para uma análise antropológica do carnaval brasileiro, ver DaMatta (1997b).
} 
formam uma tríade que deve ser entendida de forma correlacionada, como ilustra a experiência de Juarez. O contexto em que a análise dessa tríade irrompe deve ser considerado relacionalmente, pensando estrutura, relações e eixos de diferenciação.

Pensar essas circularidades tem como efeito pensar o modo aparentemente paradoxal pelo qual se articulam a gestão do segredo, a produção dos espaços como dimensões relacionais e a experiência de viver com HIV/aids. Nesse sentido, a literatura tem apontado as peculiaridades que essa microeconomia do conhecimento em torno do HIV/aids assume em cidades pequenas, com destaque para a experiência de perda de privacidade sobre sua sorologia - o que ganha contornos maiores com a progressiva interiorização da epidemia (Bellenzani; Mendes, 2011; Kaposy et al., 2017; Tavares; Melo, 2018).

Os sentidos e efeitos de escala em cidades pequena como Jardim de Piranhas requerem renunciar a noções homogeneizantes de pessoa e lugar. Ou seja, trata-se de restituir à noção de pessoa as múltiplas camadas que lhe conferem sentido em distintos contextos e momentos históricos (cf. Mauss, 2003), ou como argumentamos, algo de sua dimensão dividual, como uma subjetividade diluída em um amplo conjunto de relações (Strathern, 2006). Juarez é uma pessoa à medida que, no fluxo das relações, ele pode ser lido considerando arranjos de parentesco e compadrio, sua ocupação, religiosidade e sorologia, por exemplo.

Tais questões retomam a complexidade da noção de pessoa, tendo em vista que se trata não apenas de formas de reconhecimento, mas atributos da diferenciação social e como esses são interpelados e marcados corporalmente. É preciso pensar o modo como eixos de diferenciação de geração, sexualidade, gênero, raça, e no caso aqui argumentado, sorologia e lugar de origem, participam da conformação e organização dessas relações. Juarez é um homem gay, lido como branco, já com mais de 60 anos, que retornou à cidade após ter vivido no Rio de Janeiro. Para algumas pessoas, a sorologia pode ser um elemento distanciador, requerendo o segredo, ou aproximador, produzindo identificação. Essas categorias se articulam na produção da experiência social e no modo como sua presença é interpretada cotidiana e institucionalmente na organização do poder. Elas devem ser lidas de forma interseccional, ou seja, analiticamente pensadas tomando como corpos e subjetividades são constituídos por eixos de diferenciação e recebidos de modos diferentes no contexto de relações interpessoais, disciplinares, culturais e estruturais (Collins; Bilge, 2016). Dadas a distribuição diferencial de privilégios e a mecânica de injustiças, considerar como subjetividades políticas são forjadas no encontro entre processos de marcação de corpos e sua recepção no tecido social são indispensáveis para pensar o sofrimento social, a dor e o estigma.

A microeconomia do conhecimento que participa de noções como público, privado $e$ intimidade têm rendimentos na produção de categorias locais, como consideração, respeito, confiança que sinalizam para expectativas em torno das relações, dos elementos que as constituem, e nas possibilidades de reconhecimento no contexto da subjetividade política. Como demonstramos aqui, a experiência de controle moral da sexualidade e da linguagem não é exclusiva de cidades pequenas, mas poderíamos dizer que tem uma elasticidade maior onde os laços de convivência produzem redes de interação e contato mais restritas. Assim, o controle do corpo e o controle do espaço se aproximam. Isso porque, como argumenta Mongin (2009:242), "a experiência urbana é primeiramente corporal". Essa instância corporificada estabelece mecanismos de interpelação e disputas que são sensíveis à experiência social. Retomando Mongin (2009), em seu aspecto análogo, corpo e experiência urbana requerem a construção ou identificação do que seja interior $e$ exterior. No contexto da experiência urbana isso coloca a cidade tanto como instância administrativa de organização do espaço, como um conjunto razoável de equipamentos que permitem a vida urbana. No que tange ao corpo, isso implica o reconhecimento de diferenças $e$ relações que estabelece semelhantes e diferentes.

Ainda que Juarez partilhasse sua sorologia em espaços públicos, mesmo que circunscrita dentro dos moldes aqui apresentados, ela não foi sempre assim. Falar sobre e para estas pessoas se transformou em um instrumento de gestão do estigma e dos modos de regulação social produzidos pela fofoca como instâncias de enunciação de poder e constrição de linguagem. Esse universo de ambivalências e paradoxos que localizava em momentos distintos significados para "eu", "vírus", 
"segredo", "contar" estende-se também às próprias condições de execução da pesquisa e o modo como acessamos determinado tipo de informação e narrativas.

Em síntese, um projeto de análise dos efeitos do lugar sobre as experiências de subjetivação de pessoas vivendo com HIV/aids, a noção espacializada de contexto não pode ser subsumida a uma estrutura urbana descorporificada, onde a presença das pessoas é ausente. Ao contrário, a geografia deve ser componente de um esforço afetivo no qual são construídos lugares de memória, de relação e de posições nas quais os sujeitos são marcados e marcam a si mesmos a partir de disputas, embates, tensões e acomodações num fluxo de sentidos que acionam para si e para o mundo em que vivem no decorrer de suas trajetórias.

\section{Referências bibliográficas}

BELLENZANI, Renata; MENDES, Rúbia de Fátima. Sigilo na atenção em DST/Aids: do consultório aos processos organizacionais. Polis Psique, Revista da Pós-graduação em Psicologia Social e Institucional da UFRGS (1), Porto Alegre-RS, 2011, pp.140-165.

BESNIER, Niko. Gossip and the everyday production of politics. Hawaii, University of Hawaii Press, 2009.

BIEHL, João. Will to Live: AIDS therapies and the politics of survival. Princeton, University Princeton Press, 2007.

BRAH, Avtar. Diferença, diversidade, diferenciação. cadernos pagu (26), Campinas-SP, Núcleo de Estudos de Gênero-Pagu/Unicamp, 2006, pp.329-376.

COLLINS, Patricia Hill; BILGE, Sirma. Intersectionality. Malden, Polity, 2016.

CZERESNIA, Dina. AIDS, contágio e transmissão: relações entre epidemia, cultura e ciência. In: CZERESNIA, Dina; SANTOS, Elizabeth Moreira dos; BARBOSA, Regina Helena Simões; MONTEIRO, Simone (org.). AIDS: ética, medicina e biotecnologia. São Paulo, HUCITEC; Rio de Janeiro, ABRASCO, 1995, pp.51-76.

DAMATTA, Roberto. A casa e a rua: espaço, cidadania, mulher e morte no Brasil. 5 ed. Rio de Janeiro, Rocco, 1997a. $1997 b$.

Carnavais, malandros e heróis: para uma sociologia do dilema brasileiro. Rio de Janeiro, Rocco,

DANIEL, Herbert. Anotações à margem do viver com aids. In: LANCETTI, Antonio (dir.). Saúde Loucura, n.3. São Paulo, HUCITEC, 1991. pp.3-30. (Saúde em Debate, 47).

DANIEL, Herbert; PARKER, Richard. A terceira epidemia: o exercício da solidariedade. In: . Aids, a terceira epidemia: ensaios e tentativas: dois olhares se cruzam numa noite suja. São Paulo, Iglu Editora, 1991, pp.13-30.

DURHAM, Eunice R. A caminho da cidade. 3 ed. São Paulo, Perspectiva, 1984.

FACCHINI, Regina. Sopa de letrinhas? Movimento homossexual e produção de identidades coletivas nos anos 90. Rio de Janeiro, Garamond, 2005.

FOUCAULT, Michel. Microfísica do poder. Rio de Janeiro, Edições Graal; 2010.

GOFFMAN, Erving. Estigma: notas sobre a manipulação da identidade deteriorada. 4 ed. Rio de Janeiro, LTC, 2008.

GREEN, James N. Além do carnaval: a homossexualidade masculina no Brasil do século XX. São Paulo, Editora UNESP, 2000.

GUERRA, Verônica Alcântara. Mulheres de bens: famílias, trânsitos e afetos nas negociações morais do retorno à Paraíba. Tese (Doutorado em Antropologia), UFPE, Recife, 2019.

GUIMARÃES, Carmem Dora. O Homossexual visto por entendidos. Rio de Janeiro, Garamond, 2004.

JAMESON, Fredric. O Inconsciente político: a narrativa como ato socialmente simbólico. Rio de Janeiro, Ática, 1992.

KAPOSY, Chris; GREENSPAN, Nicole R.; MARSHALL, Zack; ALLISON, Jill; MARSHALL, Shelley; KITSON, Cynthia. Clinical ethics issues in HIV care in Canada: an institutional ethnographic study. BioMed Central, Medical Ethics (18), London - UK, 2017, pp.1-13. 
KLEINMAN, Arthur; DAS, Veena; LOCK, Margaret. Introduction. In: (ed.). Social Suffering. Berkeley, University of California Press, 1997, pp.ix-xxvii.

MANN, Jonathan, WHO Special Programme on AIDS. Statement at an informal briefing on AIDS to the 42nd session of the United Nations General Assembly on Tuesday 20th October 1987. Geneva, World Health Organization,

[https://apps.who.int/iris/bitstream/handle/10665/61546/WHO SPA INF 87.12.pdf?sequence=1\&isAllowe $\mathrm{d}=\mathrm{y}-$ acesso em: 10 jun. 2021].

MARQUES, Roberto. Cariri eletrônico: paisagens sonoras no Nordeste. São Paulo, Intermeios, 2015.

MAUSS, Marcel. Sociologia e antropologia. São Paulo, Cosac Naify, 2003.

MONGIN, Olivier. A condição urbana: a cidade na era da globalização. São Paulo, Estação Liberdade, 2009.

PARKER, Richard. Abaixo do Equador: cultura do desejo, homossexualidade masculina e comunidade gay no Brasil. Rio de Janeiro, Record, 2002.

PATRICIO, Maria Cecília. No truque: transnacionalidade e distinção entre travestis brasileiras. Tese (Doutorado em Antropologia), UFPE, Recife, 2008.

PATTON, Cindy. Inventing AIDS. New York, Routledge, 1990.

PERLONGHER, Néstor. O que é aids. 2 ed. São Paulo, Editora Brasiliense; 1987 (Coleção Primeiros Passos; 197).

PEREIRA, Pedro Paulo Gomes. O terror e a dádiva. Goiânia, Editora Vieira; Cânone Editorial, 2004.

RABINOW, Paul. Antropologia da razão. Rio de Janeiro, Relume-Dumará, 1997.

RABINOW, Paul; ROSE, Nikolas. O conceito de biopoder hoje. Política e Trabalho (24), João Pessoa-PB, 2006, pp.27-57.

RUBIN, Gayle. Pensando o sexo: notas para uma teoria radical da política da sexualidade. In: Políticas do sexo. São Paulo, Ubu, 2017, pp.63-128.

SADEQ, Rahimi. Meaning, Madness and political subjectivity: a study of schizophrenia and culture in Turkey. Londres, Routledge, 2015.

SAGGESE, Gustavo Santa Roza. De afetos, diferenças e superações: aids, subjetividades e transformação social entre homens homossexuais em São Paulo. Bagoas, Revista de Estudos Gays (9), Natal-RN, 2015, pp.31-56.

SANCHES, Hoster Older; BARBOSA, Pedro Luis Navarro. Elementos discursivos da governamentalidade do corpo das populações em enunciados midiáticos sobre a aids, nos anos 1980. Cadernos de Estudos Linguísticos (57), Campinas-SP, 2015, pp.141-55.

SANTOS, Emelynne Gabrielly de Oliveira; BARBOSA, Isabelle Ribeiro. Conglomerados espaciais da mortalidade por suicídio no nordeste do Brasil e sua relação com indicadores socioeconômicos. Cadernos Saúde Coletiva (25), Rio de Janeiro-RJ, 2017, pp.371-378.

SONTAG, Susan. Aids e suas metáforas. São Paulo, Companhia das Letras, 1989.

STRATHERN, Marilyn. O gênero da dádiva: problema com as mulheres e problema com a sociedade na Melanésia. Campinas, Unicamp, 2006.

TAVARES, Thais Raquel Pires; MELO, Lucas Pereira de. "A gente vive em cima da corda bamba": experiência de profissionais da saúde que trabalham com o HIV/aids em uma área remota do Nordeste brasileiro. Cadernos de Saúde Pública (34), Rio de Janeiro-RJ, 2018, e00063618.

TREICHLER, Paula A. AIDS, homophobia and biomedical discourses: an epidemic of signification. October (43), Cambridge-USA, 1987, pp.31-70.

TREVISAN, João Silvério. Devassos no paraíso: a homossexualidade no Brasil, da colônia à atualidade. 3 ed. Rio de Janeiro, Record, 2000.

VALE, Alexandre Fleming Câmara. $O$ voo da beleza: travestilidade e devir minoritário. Tese (Doutorado em Sociologia), UFC, Fortaleza, 2005.

VERAS, Elias Ferreira. Travestis. carne, tinta e papel. Curitiba, Ed. Prismas, 2017. 
ZAMBONI, Marcio. Aids, longa duração e o trabalho do tempo: narrativas de homens que vivem com HIV há mais de 20 anos. Política \& Trabalho, Revista de Ciências Sociais (42), João Pessoa-PB, 2015, pp.69-90. 